\title{
Recidivism with Opiate Addicted Patients on Buprenorphine Substitution Treatment: Case Report
}

\author{
Katarina B. Crnić́ ${ }^{1}$, Mirjana M. Todorović ${ }^{2}$ \\ ${ }^{1}$ Special hospital for addictions, Belgrade, Serbia \\ ${ }^{2}$ Specialized psychiatric clinic "Ramah", Belgrade, Serbia
}

\section{SUMMARY}

Introduction: Opiate dependence is a serious, chronic and recurrent psychiatric disorder, whose prevalence reach epidemic proportions. This also contributes to a significant increase in mortality, associated with overdose with opiates, as well as the rise in other health and social problems of the society. The methods and availability of treatment do not correspond to increased treatment needs, and treatment success is limited by the characteristics of the disorder, or numerous risk factors, which contribute to a high percentage of recidivism. Good clinical practice guidelines have defined treatment recommendations that include high and low-demanding programs. The personalized and integrative approaches are emphasized.

Case report: The patient aged 41 years, intravenous-use opiate addict from his adolescences, with numerous psychological, health and social complications of addiction, is a participant in institutional treatment, following a court order as a measure of obligatory treatment, due to criminal offenses related to addiction. The history of the disease refers to numerous unsuccessful attempts to heal and short-term abstinence in the past, mainly in penal institutions. The patient meets all the criteria defined by the guidelines for inclusion in the buprenorphine maintenance program started in the year 2013. During the four-year treatment, the doses of the drug were adapted as needed; two heroin relapses and many in-risk situations for relapse were registered. The treatment continuated with close monitoring of the patient's condition and, with appropriate psychosocial interventions, contribute to keeping the patient in treatment and preventing the development of new complications of addiction, as well an improving the quality of his life.

Discussion: Pharmacological treatment of opioid dependence relies on agents belonging to groups of antagonists, agonists and partial agonists of opiate receptors. The earlier programs with abstinence as a treatment goal have significantly allocated the place to "harm reduction" programs, where the therapeutic goals are less demanding and defined as the harm-reduction of opiate dependence on the individual and the society. Treatment guidelines define the principles and types of treatment regimens with agonists and partial agonists of opiate receptors and most commonly used are methadone and buprenorphine. The high risk of relapses despite treatment is defined and a comprehensive approaches and inclusion of Cognitive Behavior Therapy /CBT/, family and social therapy are needed. 
Conclusion: Defining opioid addiction as severe, chronic and recurrent disease, with high prevalence and mortality rate, forces a therapeutic approach similar to the other chronic and widespread diseases in the population. First of all this implies changing treatment goals, in terms of controlling and reducing harm to individuals and society, and then increasing the availability of treatment at the level of primary care outside the hospital and psychiatric institutions. In addition to pharmacological approachmaintenance programs, psychosocial programs are also needed to contribute to the better treatment outcome.

Keywords: dependence, opiates, maintenance, buprenorphin

\section{INTRODUCTION}

Opiates and opioids are natural and medicinal substances, which due to their analgesic activity are applied primarily in the treatment of pain. Through the centuries, abuse and dependence on opiates is also known, and recognized as a severe psychiatric disorder, characterized by chronicity and recidivism, regardless of the different treatment options. DSM-5 defines opioid dependence as a "problematic form of opiate use, which leads to clinically significant incompetence and distress". It is characterized by craving, increasing tolerance, abstinence syndrome and continuous abuse despite personal and social problems, as well as other behavioral changes. Similar criteria include ICD10: strong desire or compulsive need to take substance, difficulties in controlling behavior, abstinence crisis when use is interrupted, increased tolerance, progressive neglect of other interests and pleasures, persisting abuse of the substance despite the presence of obvious harmful consequences.

Opioid dependence caused by the use of illicit drugs or opiates and opioids prescribed, has been increased in the past 20 years [1]. It is estimated that 26 to 36 million people worldwide abuse opiates, of which 2.1 million in the United States, contributed by more than three times the number of opioid prescriptions that were issued from 1990 to 2015 [2]. Opportunities and treatment availability are insufficient for increased treatment needs. This is accompanied by increase in opiate overdoses and deaths, and in the United States data on a tenfold increase since the year 1999 are reported, and epidemic proportions are discussed [3]. By contrast, in Europe, there is a certain decline in the number of opioid addicts, starting from 2011 e.g. data for 2014th indicate the average prevalence of high-risk opiates $0,4 \%$ in the adult population aged 18-64 years, which is still 1.3 million of high-risk consumers. Number of new opiate users in Europe decreased by almost half - from $36 \%$ in 2007 to $17 \%$ in the 2013 [4]. The situation in Serbia, estimated in year 2005, 2011 and 2015 in samples in the general population of adults aged 18-64 years and the young population of high-school students at the age of 16. In adult population the lifetime prevalence is $7-8 \%$ for all illegal drugs and $0.9 \%$ for heroin, and $12.8 \%$ for all illegal drugs and 0.6-0.9 for heroin, in the younger population. These percentages were stable in observed periods and similar as in the region of the West Balkan countries, but lower then in developed Western European countries [5-8]. Mortality rates in Europe, associated with opiates overdose in 2014 accounted 6800 deaths, [4] while for Serbia this number is decreasing41 deaths due to overdose of illegal drugs, 18 due to opiates in 2015, compared to 53 in 2007, 62 in 2008, 119 in 2009 [8].

In addition to the negative impact of the use of opiates on the psychological state and way of life, many health problems are associated with this dependence, e.g. serious cardiac abnormalities, increased risk of HIV infection and its complications, Hepatitis C, tuberculosis, etc.

Nowadays different therapeutic options for treatment of opiate dependence are defined $[9,10]$. Depending on the therapeutic goals, treatment programs can be divided into highly demanding, which means complete and long-lasting abstinence and low demanding, "harm- reduction programs", that involve prolonged substitution therapy. One pharmacotherapy program can be replaced by another depending on the circumstances. In addition to pharmacotherapy, an integrative approach, which provides psychotherapeutic and social therapeutic support, is considered as the most 
successful. The World Health Organization in 2009 published Guidelines for the Psychosocial Supported Pharmacological Treatment of Opioid Dependence [4], where the basic recommendations for therapeutic programs were set at the national levels and there was a significant place occupied with "harm- reduction" orientation.

Following the guidelines of the World Health Organization in the countries of the European Community, national guidelines have been formulated and they recommend the implementation of substitution therapy for opiate addicts as part of public health institutions in the form of long-term intervention, similar to other chronic diseases (cardiovascular diseases, Diabetes mellitus, infectious diseases). Also, at the European Union level, efforts are being made to ensure that regulations and professional attitudes are harmonized in all countries in relation to the application of these programs. The national strategy in Serbia is defined in the National Guidelines for the treatment of opiate and opioid addicts [10], published in April 2010, where the expert framework for the application of substitution therapy is defined.

It has already been emphasized that dependence on opiates is considered as severe and chronic disease. The National Institute on Drug Abuse in the United States has stated that about $40-60 \%$ of addicts are relapsed, while for heroin addicts that percentage goes up to 80 to $91 \%$, with $59 \%$ being relapsed during the first week after the treatment is completed, and $80 \%$ during the first month of abstinence [11]. This high percentage of relapse is similar to other chronic diseases, such as Diabetes mellitus, arterial hypertension, asthma, and similar treatment is proposed in the treatment. The experience of the Special Hospital for Addiction in Belgrade also indicates a high percentage of relapses among treated opiate addicts, a large number of unsuccessful treatments in drugfree programs and a significant percentage of health, psychological and social complications of this addiction [10].

\section{CASE REPORT}

Patient aged 41 years old, heroin addict, has been treated in the specialized institution for addiction since 2010 and currently involved in the day hospital mandatory treatment by a court order since 2013 due to criminal offenses related to opiate addiction. Attended secondary school, unemployed, unmarried, having a 10 year old son from previous partnership relation, now living with a new partner.

\section{Addiction anamnesis:}

The first contact with psychoactive substances was at the age of 15 , with marijuana, out of curiosity, indifferent, but still continues to consume it until mid 2013. He was also using alcohol, Trodon and Bensedin tablets, "speed", LSD, cocaine and ecstasy.

First contact with heroin was at the age of 17, affirmative experience, and immediately started intravenous usage.

Addictive pattern of abuse existed since he was 21 , daily intravenous taking of the drug until the first hospitalization in the year of 2010, abstinences were short 3-6 months, mostly in penal institutions.

Patient overdosed with heroin on two occasions.

Virus status: HCV positive, HIV negative.

Patient served the prison sentences twice for opiate dependence related crimes: at the age of 20, a year in prison, and at the age of 27 in a prison hospital. Currently, a judicial process is under way for a similar criminal offense; it is presumed that the mandatory treatment of addiction will be imposed again.

\section{Personal history:}

Patient is the second born child, the early psychomotor development was neat, went to elementary school and graduated on time, enrolled in a secondary school, graduated, served his entire military service. Previous partner relationship, with a 10 year old child now, was conflicting and discontinued due to dependency problems. Current partner relationship is satisfied, they live together in his own flat.

When the patient was 19 years old he underwent the lower jaw fracture, in the 2009, suffered from right leg thrombosis and in the 2010 left leg thrombosis (in both cases the result thereof was the intravenous taking of drugs), rehabilitated. No allergies. Smoker.

\section{Family history:}

Parents are in their 60's, retired, healthy, their marriage is good, older sister is healthy, has her own family. There is no psychiatric illnesses history in the family. 
In the present mental status:

Adequate appearance, medium communicative, right oriented in all directions, no perceptive disturbances, attention and memory preserved, average intelligence, adequate ideation form and content, There is slightly lowered mood, anxiety is a bit elevated, emotional resonance is established. The depressive affect is observed when confronting with their inefficiency and poor "problem solving" abilities. The initial insomnia and diminished volition are present. There are no suicidal ideas or plans. The frustration tolerance is extremely low, impulsivity and acting out are observed at the minimum pressure. Critical judgment and insight are partially preserved, but the value system is completely inverted and negative Although the motivation for treatment is imposed by mandatory treatment, there is a motive for participation in the treatment and respecting of the program.

\section{Treatment of opiate dependence:}

The institutional treatment started in 2010 and diagnosed F 11.2, Status post phlebotrombosis femoropoplitealis lat sin, St post phlebotrombosis lat. dex., Oedema femoris et cruris lat. Dex, for the purpose of detoxification. He left the treatment on his own initiative.

Patient in 2013 is back on treatment for the purpose of implementing the court order of mandatory treatment, due to crimes related to his addiction. He was admitted to the Day Hospital unit, substitution therapy with Buprenorphine was suggested, Buprenorphine maintenance program started on October 2013. The dose of Buprenorphine was $6 \mathrm{mg}$, with additional medication with antidepressants and anti-anxiety agents, as well as a complete psychosocial program. The urine test for the opiates was negative. By the end of 2013, the dose of buprenorphine was $8 \mathrm{mg}$, and he stopped using marijuana as well.

During the treatment in 2014, his mood was more stable, with better impulse controlling, but presence of sleep inversion despite of medication was observe, and patient does not accept significant obligations in real life.

He continued with substitution therapy within primary care and after two months he made a relapse with heroin, registered after infectious complications on the skin due to needle sticking in November 2014. , when he was again sent to the institution after the court's remark, because the treatment was interrupted on his own initiative. Detoxification from heroin with buprenorphine was performed, and he was back to the buprenorphine maintenance program at a daily dose of $6 \mathrm{mg}$ to the competent Health Center, with controlling and social therapy program at the institution. By the end of 2014, the urine tests for opiates were negative, with the proper administration of the prescribed dose of buprenorphine. The dose of buprenorphine was adjusted to $8 \mathrm{mg}$ in April 2015. with additional anti- anxious medication. He made a relapse with heroin in May 2015 that he concealed, did not use adequate therapy. After facing the facts that he relapsed because of non compliance with the program and the treatment was endangered, with adequate monitoring of the program, he abstained until October, with the reduction of anxiety and progress in the program. In October 2015, crises were reported on screening, a return to old patterns of behavior was observed, and a dose of buprenorphine was increased in order to prevent relapse, and a satisfactory condition was maintained by the end of 2015. During 2016 he was stable, no crisis, with better integration in society, which he changed, found a more adequate partner, and intensified his relationship with his child. At the beginning of 2017 the situation is satisfactory, but soon there is a crisis with inadequate behavioral patterns, which he did not recognize. The risk of a new recurrence is currently resolved with intensive counseling and taking a prescribed dose of medication. Now he is planning employment and advantage in treatment is observed.

\section{DISCUSSION}

The recurrence of opiate dependence is explained by the profound and long-lasting changes in the functioning of certain brain regions, especially those pertaining to the reward mechanism of the Central Nervous System (CNS), which is the basic pathogenetic mechanism of the disease dependence in general [12]. The reward mechanism of the CNS is a complex neural network, which includes mostly dopaminergic neurotransmitter centers and pathways, but also their links to serotonergic and other neurotransmitter systems. Opiate and opioid administration triggers direct opioid $\mu$ receptors in the mid brain, with consecutive activation of the neuron of the ven- 
tral tegmentary area of the medulla oblongata, which, with its projections toward the nucleus accumbens, is the origin of the mesolimbic dopaminergic neuronal network. Its connection with the amygdala nuclei provides the experience of satisfaction and pleasant emotions, but also the process of learning and fixing the learned positive emotional experience. Chronic use of opiates leads to biochemical and structural changes in these structures and leads to the anticipation of experienced pleasure- craving. Also, connection with the mezocortical dopaminergic pathways, allows the compulsive behavior of purchasing and taking drugs, without the possibility of a significant influence of will, the processes of logical thinking, possible risk and damage assessment, behavior control. At later stages, structural disorders are deepening; there is a reduction in the number of dopamine receptors, leading to even more intense cravings and an increase in tolerance [13].

There are also a number of risk factors, related to the person himself, his genetic characteristics, personality traits, and acquired patterns of behavior related to addiction and from the environment, which can contribute to increasing the likelihood of recurrence.

If opiate dependence is considered as a chronic, severe and widespread disease and advocates a therapeutic approach similar to other chronically illnesses, the principles of pharmacological treatment must first be defined by the already mentioned guidelines of Good Clinical Practice (GCP) the world-wide and at national level.

The pharmacotherapeutic approach relies on four groups of psychopharmaceuticals related to their affinity for opiate receptors in the central nervous system [10]:

1. Opioid receptor agonists-methadone

2. Partial opioid receptor agonists- buprenorphine

3. Opioid receptor antagonists-naltrexone

4. Symptomatic-clonidine, tramadol

The "gold standard" of the treatment of opioid dependence is antagonist therapy, which implies a detoxification phase and maintenance phase with a certain stable dose of naltrexone (the usual daily dose is $50 \mathrm{mg}$ ). These programs often represent a hard-reaching goal, with the problem of recidivism, and numerous unsuccessful treatments.

Therapeutic requirements and goals, defined by the recommendations for the treat- ment of opioid dependence, have become less rigid [9]. The ultimate goal of the treatment does not have to be a "drug free" patient, but a longer stay in treatment, better health and social functioning, reducing the use of illegal drugs, reducing mortality associated with drug abuse, controlling the risk of transmittable diseases - HIV infection, hepatitis B and $\mathrm{C}$, tuberculosis, crime prevention, cost reduction caused by the problem of dependence in society.

Its goals can be reached by the "harm reduction" programs, where basic recommendations for opiate substitution therapy were set. That is defined as a strategy of controlling, rather than the prevention of opiate use. It implied prescribing and controlled administration of opioids with prolonged action with less euphoric effect, in order to reduce craving and to prevent abstinence symptoms.

One of the first, starting from 1965, and the most commonly used opioids in the replacement-maintenance therapy, is methadone, which, in its pharmacological activity, is the complete opioid $\mu$ receptor agonist. It is characterized by a slow increase in maximal blood concentrations (4 hours), long half-life (25 hours), which supports its therapeutic efficacy, but also the cumulative effect after repeated dose and increased tolerance, indicating its addictive potential. Numerous of clinical studies $[15,16]$ have shown its effectiveness, both on the underlying clinical symptoms of addiction, and on social and health implications, such as reducing the risk for HIV, reducing the addiction-related crime. The effectiveness of methadone therapy in terms of treatment retention and recidivism varies from study to study [16], from $20 \%$ to $70 \%$, with a number of factors being affected as a genetic variability, specific metabolic characteristics, other medication, the use of other psychoactive substances, etc. [17]. Pharmaco-economic studies support its use, but several recent studies show the occurrence of cardiac side effects, such as QT prolongation, indicating the need for medical supervision of patients in methadone maintenance treatment [18]. Its negative characteristics, high addictive potential, are often the cause of abuse, addiction, and overdose.

The data suggest that about $20-25 \%$ of opiate addicts in the United States use methadone in maintenance therapy [14], compared to other forms of therapy and those who are not on therapy at all. In Europe, $70 \%$ of opi- 
ate addicts are on substitution therapy use methadone, combined with psychosocial interventions. According to the data in the year of 2015 in Serbia there are about 1.430 users of substitution therapy with methadone in civilian institutions, and 487 in prisons, which is increase compared to the data in 2011 [8].

In early 2007, there has been an increase in other types of substitution therapy, including buprenorphine, a partial agonist of opiate receptors. Its application was initiated between 1990 and 2000 in some European Union countries and in Australia, and since 2002 in the United States also. Buprenorphine has a slower onset and a longer duration of action, which allows dosing ones per day or once per every second or third day. It has a lower risk of over-dosage due to specific action - in larger doses it blocks itself leading to an antagonistic effect. High doses have milder opiate activity than complete agonists, but also lower maximum efficacy in severe addicts. Symptoms of buprenorphine abstinent crises are milder and buprenorphine more easily switches to naltrexone than methadone if detoxification is planned. Its recommended maximum dose is $32 \mathrm{mg}$, compared to $60-100 \mathrm{mg}$ of methadone [10]. Numerous clinical studies confirm its efficacy in relation to placebo; also studies on the use of buprenorphine in primary care and in private practice [20] confirm that its application leads to a reduction in mortality due to overdose, a reduction in the number of heroin addicts, an improvement in the social and medical status of addicts, and a longer patient retention in treatment. It emphasizes its convenience in home care, good compliance, less impact on psychomotor abilities (driving, work).

Studies of the efficacy of buprenorphine and methadone give inconsistent results, depending on various factors, such as dose height and application flexibility $[15,16$, 21] Also, the age, sex, length of heroin using, the severity of the symptoms of dependence, have an impact on the effectiveness of treatment by one or the other drug, so there are different recommendations for the "first line" in the treatment. The higher market price of buprenorphine restricts its widespread use compared to methadone. In Serbia, the data of 2015. indicate 852 users of buprenorphine substitution therapy, compared to only 79 in 2011 [8].

It should be noted that buprenorphine is the therapy of choice in specific groups of opiate addicts, such as HIV positive, pregnant women, adolescents [21].

Guidelines for substitution therapy in opioid addicts also defined criteria for inclusion in these programs [5]:

-The age limit of at least 18 years

- Length of opiate addiction at least 5 years

- Clearly met the criteria of MKB 10 / DSM 5

for the opiate dependence

- More unsuccessful attempts at treatment in the past

-Opiate dependence associated with other chronic psychiatric disorders

- Opiate dependence associated with criminal behavior

- Opiate dependence associated with HIV infection and other transmissible infections

-Motivation to enter the program

Also, a detailed dose regimen, urine tests on psychoactive substances and drugs, rules of behavior for patients and staff of the medical institution are defined.

It has already been noted that in addition to neurobiological factors, which are responsible for the occurrence of recidivism in opiate dependence, there are many other psychological, social and other factors that come from the person and the environment, which can have a significant impact on increasing the risk of relapse and maintaining dependence [22]. The assessing these factors for each patient is a significant part of the therapeutic process, followed by appropriate therapeutic actions, which includes the elements of the psychotherapeutic and social therapeutic approaches, in order to support the results of the pharmacotherapy treatment and as much as possible reduce the risk of relapse [23]. It is emphasized that opiate dependence affects the whole person, both the biochemistry of her brain, and her psychological and social functioning. So, the treatment modalities should be the approach to all the mentioned aspects of the disorder. It is emphasized that, within the framework of an integrative treatment, relapses are not a sign of failure of treatment, but are the reason for the therapy to continue, as well as to change therapeutic modality. Relapses are often disappointing for patients themselves, they lead to negative emotions, depression, hopelessness, isolation, which activates old maladaptive behavioral patterns and leads to return to drug use. Therefore, the existence of a social network and social therapy interven- 
tions, post-pharmacological treatment, prolonged treatment, and all forms of support for continued treatment are very important.

\section{CONCLUSION}

Opiate dependence is a difficult, chronic and highly recurrent psychiatric disorder, which over the past decades has reached epidemic proportions on a global scale. In addition to the detrimental impact on the individual's mental and physical health, many public health and social burdens are associated with this addiction, such as an increased risk of spreading transmission diseases-HIV, TB, Hepatitis C, high crime rates, economic burden on society, increased mortality rates due to overdose. Opportunities and treatment availability are not sufficient for increased treatment needs. In addition to highly demanding therapeutic programs, which include long-term abstinence in protected conditions, the World Health Organization and the correspondingly most healthcare institutions in the European Union and other countries have developed harm -reduction programs, substitution therapy with agonists and partial agonists of opiate receptors. The proclaimed treatment objectives are patient retention in the program, restriction of the use of illegal drugs, intravenous drug use, mortality rates from overdose, control of the risk of spreading transmission diseases, and criminal drug-related behavior.

Pharmacological agents used in substitution therapy programs are most commonly methadone and, more rarely, other opiate agonists, and recently buprenorphine, a partial opiate agonist, which is the therapy of choice in outpatient treatment, as well as the treatment of special categories of addicts. Antagonist maintenance programs are also present, i.e. Naltrexone, or a combination of naloxone and buprenorphine / suboxone /, as well as the possibility of replacing one program with others.

Due to the problem of recidivism, which has numerous neurobiological, psychological and environmental causes and risk factors, a personalized and integrative approach to the treatment of opiate addicts is required, which includes a pharmacological treatment, combined with psychosocial and other support programs. It is emphasized that relapse is not a reason for termination of treatment, but for continuation, with adjustment or change program of treatment $[22,24]$.

\section{REFERENCES}

1. Ezzati M, Lopez AD, Rodgers A, VanderHorn S, Murray CJ. Selected major risk factors and global and regional burden of disease. Lancet. 2002; 360(9343): 1347-1360

2. Schuchat A, Houry D, Guy G.P. New Data in Opioid Use and Prescribing in the United States. JAMA. Publisched online July 6, 2017. Doi: 10.1001/ jama.2017.8913

3. Rudd RA, Seth P, David F, Scholl L. Increases in drug and opioid-involved overdose deaths-United States, 2010-2015. MMWR Morb Mortal Wkly Rep. 2016; 54(10):1445-1452

4. Usporedba stanja problematike droga u Republici Hrvatskoj i Europi 2014. Izvješće o provedbi Nacionane strategije i Akcijskog plana suzbijanja zlouporabe droga u 2015. Republike Hrvatske. https:// drogeiovisnosti.gov.hr

5. Manzoni MJ, Bjegovic V, Jankovic-Ciric S, Prepeliczay S. School survey project on the use of alcochol and other drugs among youth in Serbia 2005. Ministry of Health Republic of Serbia, Belgrade. 2005.

6. Serbia: Country Overviev 2009. European Monitoring Centre for Drugs and Drug Addiction Publication 2009. Publication Ofice of the European Union 2009. ISBN 97-92-9168-403-8 www.emcdda.europa. eu

7. Evropsko istraživanje o upotrebi alkohola i drugih droga među mladima u Srbiji 2008: izveštaj za republiku Srbiju. Ministarstvo zdravlja Republike Srbije i Institut za javno zdravlje „, Dr Milan Jovanović Batut"/European survey of alcochol and drugs abuse in yough in Serbia 2008. (on Serbian) 2009. ISBN 978-86-7358-047-0 www.emcdda.europa.eu , www.batut.org.rs

8. Serbia: National Drug Report 2017. European Monitoring Centre for Drugs and Drug Addiction Publication 2017. Publication Office of European Union ISBN 978- 92-9497-190-6 www.emcdda.europa.eu

9. Nichols L, Bragaw L, Ruetch C. Opioid dependence treatment and guidelines. J. Menage Care Pharm. 2010; 16(Suppl.B): S14-S21

10. Daragan-Saveljic J, Vucetic-Arsic S, Raicevic S, Baskot S, et al. Tretman zavisnika od opijata i opioida: Nacionalne smernice za lekare u primarnoj zdravstvenoj zastiti / Opiate and opioid addicts treatment: National guidelines for primary care. (on Serbian) Publikacija Ministarstva Zdravlja Srbije. April 2010. www.zdravlje.gov.rs

11. Smith BP, Barry J, Keenan E, Ducray K. Lapse and relapse following inpatient treatment of opiate dependence. Irisch medical Journal. 2010; 103(6): 176-179Whelan PJ, Remski K. Buprenorphine vs Methadone Treatment: A Rewiew of evidence in 
both developed and developing worlds. J. Neurosci Rural Pract. 2012; 3(1): 45-50

12. Kosten TR, George TP. The Neurobiology of Opioid Dependence : Implication for treatment. SciPractPerspect. 2002; 1(1): 13-20Mattick RP, Ali R, White JM, O'Brien S, Wolk S, Danz C. Buprenorphine vs Methadone maintenance therapy: a randomized double-blind trial with 405 opioid dependent patients. Addiction. 2003; 98(4): 441-452

13. Koob GF, LeMoal M. Drug addiction, dysregulation of reward, and allostasis. Neuropsychopharmacology. 2001; 24(2): 97- 129

14. Stotts AL, Dodrill CL, Kosten TR. Opioid dependence treatment: Options in Pharmacotherapy. Expert OpinPharmacother. 2009; 10911): 1727-1740

15. Whelan PJ, Remski K, Buprenorphine vs. Methadone Treatment: A Rewiew of evidence in both developed and developing worlds. J Neurosci Rural Pract. 2012; 3(1): 45-50

16. Mattick RP, Ali R, White JM, O'Brien S, Wolk S, Danz C. Buprenorphine vs Methadone maintenance therapy: a randomized double- blind trial with 405 opioid dependent patients, Addiction. 2003; 98(4): 441-452

17. Samaan Z, Bawar M, Dennis B, Plater C, Worster $A$, Desai D, Thabane L, Pare G. Genetic influence in methadone dose and response to treatment in patient undergoing Methadone Maintenance Treatment (MMT) for opioid addiction: a pilot study. J. Neuropsychiatr Dis Treat. 2014; (PMC free article) (PubMed)

18. Ehret GB, Voide C, Gex-Fabry M, Chabert J, Shah D, Broers B, et al. Drug-induced long QT syndrome in injection drug users receiving methadone: high frequency in hospitalized patients and risk factors. Archives of internal medicine. 2006; 166(12): 1280- 7

19. Gowing LR, Farrell M, Bornemann R, Sullivan LE, Ali RL. Brief report: Methadone treatment of injection opioid users for prevention of HIV infection. J Gen Intern Med. 2006; 21(2): 193-5

20. Fiellin DA, Pantalon MV, Pakes JP, O'Connor PG, Chawarski M, Schottenfeld RS. Treatment of heroin dependence with buprenorphine in primary care. The American journal of drug and alcochol abuse. 2002; 28(2): 231- 41

21. Connock M, Juarez-Garcia A, Jowett S, Frew E, Liu Z, Taylor RJ, et al. Methadone and buprenorphine for the management of opioid dependence: a systematic review and economic evaluation. Health tehnology assessment (Winchester, England). 2007; 11(9):1-171

22. Volkov N. Treatment and recovery. Drug, Brains, and Behavior: The Science of Addiction. $\mathrm{NIH}(\mathrm{Na}-$ tional Institute on Drug Abuse) Publication, July 2014

23. Ramah A, Todorovic M, Crnic K. Flumazenil in
Treatment Benzodiazepine Withdrawal Syndrome: Case Report. Hospital pharmacology. 2015; 2(2): 261-265

24. Crnic KB, Todorovic MM, Markovic SZ, Kastratovic DA, Timotijevic IP. Addiction and depression comorbidity approaches. Hospital Pharmacology International Multidisciplinary Journal. 2016; 3(3): 440-446 (www.hophonline.org) 


\title{
Recidivantnost kod opijatskih zavisnika na supstitucionoj terapiji buprenorfinom - prikaz slučaja
}

\author{
Katarina B. Crnić́ ${ }^{1}$, Mirjana M. Todorović ${ }^{2}$ \\ ${ }^{1}$ Specijalna bolnica za bolesti zavisnosti, Beograd, Srbija \\ ${ }^{2}$ Specijalistička psihijatrijska ordinacija „Ramah“, Beograd, Srbija
}

\section{KRATAK SADRŽAJ}

Uvod: Zavisnost od opijata je težak, hronični i recidivantni psihijatrijski poremećaj, čija rasprostranjenost dostiže epidemijske razmere. To doprinosi i značajnom porastu mortaliteta, vezanog za predoziranje opijatima, kao i porastu drugih zdravstvenih i socijalnih problema društva. Metode i dostupnost tretmana ne odgovaraju povećanim potrebama za lečenjem, a uspešnost tretmana je ograničena karakteristikama poremećaja, odnosno brojnim rizičnim faktorima, koji doprinose recidivizmu u visokom procentu. Vodiči dobre kliničke prakse su definisali preporuke za tretman, koje uključuju visoko i nisko zahtevne programe. Pri tom se naglašava neophodnost personalizovanog i integrativnog pristupa.

Prikaz slučaja: Pacijent 41 god., i.v. zavisnik od opijata od adolescencije, sa brojnim psihičkim, zdravstvenim i socijalnim komplikacijama zavisnosti, učestvuje u institucionalnom tretmanu, po odluci suda kao mere obaveznog lečenja, zbog krivičnih dela u vezi sa zavisnošću. $U$ anamnezi bolesti se pominju raniji neuspešni pokušaju lečenja i kratkotrajne apstinencije, uglavnom u penalnim uslovima. Pacijent zadovoljava sve kriterijume definisane smernicama za uključivanje u program održavanja buprenorfinom, u koji je uključen 2013. godine. Tokom četvorogodišnjeg tretmana su doze leka prilagođavane potrebi, registrovana su dva recidiva sa heroinom i više rizičnih situacija sa pretećim recidivom, pri čemu lečenje nije prekidano, a stalno praćenje stanja pacijenta i odgovarajuće psihosocijalne intervencije doprinose zadržavanju pacijenta u tretmanu i prevenciju razvoja novih komplikacija zavisnosti, kao i poboljšanje kvaliteta života.

Diskusija: Farmakološki tretman opijatske zavisnosti se oslanja na agense koji spadaju u grupe antagonista, agonista i parcijalnih agonista opijatskih receptora. Raniji programi sa apstinencijom kao ciljem tretmana su značajno ustupili mesto „harm reduction“ programima, gde su terapijski ciljevi manje zahtevni i definisani kao kontrola štetnosti opijatske zavisnosti po individuu i društvo. Vodiči i smernice tretmana definišu principe i vrste terapije odžavanja agonistima i parcijalnim agonistima opijatskih receptora, najčešče su u upotrebi methadon i buprenorphin. S obzirom na visoki rizik od recidivizma uprkos lečenju, potreban je celovit pristup i uključivanje kogtnitivno bihevioralne terapije, porodične i socioterapije.

Zaključak: Definisanje opijatske zavisnosti kao teške i hronične i recidivantne bolesti, sa visokom prevalencijom i stopom smrtnosti, nameće terapijski pristup sličan onome za druge hronične i rasprostranjene bolesti u populaciji. To, pre svega, podrazumeva prilagođavanje ciljeva tretmana, a zatim, povećanje dostupnosti tretmana na nivou primarne zaštite, van hospitalnih i psihijatrijskih institucija. Pored farmakoloških programa, terapije održavanja, neophodni su i psihosocijalni programi, koji bi doprineli efikasnosti tretmana.

Ključne reči: zavisnost, opijati, održavanje, buprenorphin 